Jurnal Indonesia Sosial Teknologi: p-ISSN: 2723 - 6609

e-ISSN : 2745-5254

Vol. 2, No. 1 Januari 2021

\title{
PERSPEKTIF SIKAP ILMIAH MASYARAKAT TERHADAP PANDEMI COVID 19
}

\section{Eka Kartikawati, Ranti Annisa dan Maesaroh}

Universitas Muhammadiyah Prof Dr. Hamka, DKI Jakarta, Indonesia

Email: eka.kartikawati@uhamka.ac.id,e-mail@e-mail.com dan e-mail@e-mail.com

\begin{abstract}
The Covid-19 pandemic is an event of the spread of the Covid 2019 disease around the world. In the face of the Covid-19 pandemic, several scientific and nonscientific attitudes will certainly assess various circles of society as part of an attitude to see and understand the pandemic. The purpose of this study is to see the results of the analysis of the scientific perspective of the community on the Covid 19 pandemic. The method used is a descriptive method with a quantitative approach. to describe how to describe the perception of scientific attitudes which include knowledge, attitudes and behaviors that occur in various groups of people in the face of the COVID-19 pandemic. 37.5\% of respondents had an attitude of always wanting to know the latest news about Covid-19, 65.5\% of respondents asked critical questions in finding information about Covid-19 such as symptoms, its spread and prevention, An open attitude about following recommendations from the government such as following health protocols was obtained the results of $82.8 \%$ comply with it and an objective scientific attitude $37.5 \%$ of respondents answered that if they meet people who do not implement health protocols in a public place, they will reprimand them.
\end{abstract}

Keyword: scientific attitude, covid-19, critical, open attitude

\begin{abstract}
Abstrak
Pandemi covid-19 merupakan suatu peristiwa terjadinya penyebaran covid-19 di seluruh dunia. dalam menghadapi pandemi covid-19, beberapa sikap-sikap baik ilmiah dan non ilmiah pastilah akan beredar di berbagai kalangan masyarakat sebagai bagian sikap berpikir untuk mengetahui dan memahami pandemi tersebut. Penelitian ini bertujuan untuk mengetahui hasil analisis perspektif sikap ilmiah masyarakat terhadap pandemi covid 19. Metode yang digunakan adalah metode deskriptif dengan pendekatan kuantitatif. untuk mendeskripsikan bagaimana gambaran mengenai persepsi sikap ilmiah yang mencakup pengetahuan, sikap dan perilaku yang terjadi pada masyarakat dalam mengahadapi pandemic covid-19. Hasil penelitian Sebesar 37,5\% responden mempunyai sikap selalu ingin tahu berita terbaru tentang covid-19, 65,5\% responden bersikap kritis dalam mencari informasi mengenai covid-19 seperti gejala, penyebaran dan pencegahannya, sikap terbuka responden tentang mengikuti anjuran dari pemerintah seperti mengikuti protokol kesehatan didapatkan hasil sebesar $82,8 \%$ mematuhinya dan sikap ilmiah objektif sebesar $37,5 \%$ responden menjawab jika mereka bertemu
\end{abstract}


dengan orang yang tidak menerapkan protokol kesehatan di suatu tempat umum, maka akan menegurnya.

Kata kunci: sikap ilmiah, covid-19, kritis, terbuka.

\section{Pendahuluan}

Pandemi COVID-19 merupakan suatu peristiwa terjadinya penyebaran covid-19 di seluruh dunia. Virus Corona yang merupakan penyebab penyakit covid-19 menyebar dengan cepat setiap harinya (World Health Organization, 2020). Menurut Guru besar UIN Sunan Ampel Surabaya Prof. H. Masdar dalam laman harian kompas menyatakan bahwa penyebaran di Indonesia pada Tingkat mortalitas virus corona termasuk yang tertinggi $(8,46 \%)$ di Asia Tenggara akibat kegigihan.

Menghadapi pandemi Covid-19, beberapa sikap-sikap baik ilmiah dan non ilmiah pastilah akan beredar di berbagai kalangan masyarakat sebagai bagian sikap berpikir untuk mengetahui dan memahami pandemi tersebut. Konstruksi sikap-sikap ilmiah tidak selalu berhubungan langsung dengan bagian penyebab atau penyebarannya (Thorik, 2020). Konstruksi non-ilmiah tersebut justru akan menjadikan penyebaran pandemi tersebut semakin buruk. Maka dari itu, diperlukan sikap kerendahatian dari berbagai kalangan masyarakat untuk mengadakan suatu penanganan peristiwa pandemi tersebut kepada berbagai pihak yang mempunyai kewenangan serta kebijakan-kebijakan yang terkait seperti WHO, pemerintahan dan Kementerian Kesehatan. Pribadi masingmasing orang juga akan sangat membantu ikut serta dalam mensukseskan kagiatan atau kebijakan yang ada nantinya. Ada ungkapan popular yaitu jika seseorang tidak dapat menolong dalam menyelesaikan suatu masalah maka janganlah menjadi bagian dari suatu masalah tersebut. (Julianti, Nasirun, \& Wembrayarli, 2018) Hal inilah yang ingin peneliti lihat seberapa besar perpektif masyarakat terhadap pandemi covid 19 ini yang di lihat dari beberapa aspek seperti pengetahuan, sikap dan perilaku.

Hal lainnya adalah karena pada beberapa penelitian yang telah dilakukan hanya meneliti perilaku masyarakat dalam menghadapi pandemic covid 19 saja (Dana Riksa Buana, 2020), dan kiat-kiat menjaga kesehatan (Riska Dana Buana, 2017) Sedangkan pada penelitian ini bukan hanya perilaku saja yang ingin diteliti tetapi juga pengetahuannya dan sikap ilmiahnya yaitu mencakup rasa ingin tahu yang tinggi, sikap jujur, sikap kritis, sikap luwes, dan teliti. Sikap ilmiah ini penting karena sikap ilmiah akan hadir melalui proses seari-hari berdasarkan pengetahuan dan pengujian sehingga tidak muncul secara mendadak. (Surajiyo \& Sriyono, 2017)

Penelitian ini bertujuan untuk menganalisis perspektif sikap ilmiah dari berbagai kalangan terhadap pandemi covid-19 ini sehingga bermanfaat dalam mengembangkan ilmu pengetahuan yang bersumber fakta terbaru yang dapat dijadikan bahan referensi sumber informasi terbarukan mengenai sikap ilmiah yang keterkaitannya dengan pandemi covid-19.

\section{Metode Penelitian}

Metode yang digunakan dalam penelitian ini adalah metode deskriptif dengan pendekatan kuantitatif. Metode deskriptif digunakan untuk mendeskripsikan bagaimana gambaran mengenai persepsi sikap ilmiah yang mencakup pengetahuan, sikap dan prilaku yang terjadi pada masyarakat berbagai kalangan dalam mengahadapi pandemic covid-19.(Sugiyono, 2016) 
Penelitian deskriptif bertujuan sebagai penggambaran suatu fakta-fakta tentang populasi secara berurutan, dan akurat. Penelitian deskriptif ini akan disajikan apa adanya. Populasi dalam penelitian ini yaitu masyarakat kalangan umum di berbagai daerah melalui pengambilan sampel dengan teknik survei. (Sugiyono, 2012)

Teknik pengumpulan data pada penelitian ini dengan menggunakan kuesioner yang dibagikan kepada masyarakat umum melalui google form yang mencakup pertanyaan-pertanyaan mengenai persepsi dalam hal pengetahuan, sikap dan perilaku dalam menghadapi covid-19 (Iqbal et al., 2018).

Instrumen yang digunakan adalah kuesioner dengan beberapa pertanyaan yang mencakup beralasan terbuka dimana subjek penelitian harus memberikan alasan disetiap pertanyaan yang memerlukan jawaban yang beralasan. Google form tersebut mencakup beberapa pertanyaan-pertanyaan mengenai persepsi dalam hal pengetahuan, sikap dan prilaku dalam menghadapi covid-19. Penggunaan googleform ini digunakan karena lebih simple dan mudah digunakan daalm segala hal (Tri Wibawanto, 2020)

\section{Hasil dan Pembahasan}

Hasil dari pengisian kuesioner yang mencakup tentang perspektif sikap ilmiah masyarakat terhadap pandemic covid 19 diperoleh sebanyak 128 responden dari berbagai kalangan. Data responden yang mengisi kuesioner terperinci yaitu $81,3 \%$ perempuan dan 18,8\% laki-laki dari jumlah total keseluruhan 128 responden. Responden-responden yang mengisi berasal dari berbagai kalangan antara lain; Dosen, guru/ pengajar, mahasiswa, siswa, staff/karyawan, wiraswasta dan umum. Hasil data dapat dilihat pada Gambar1:

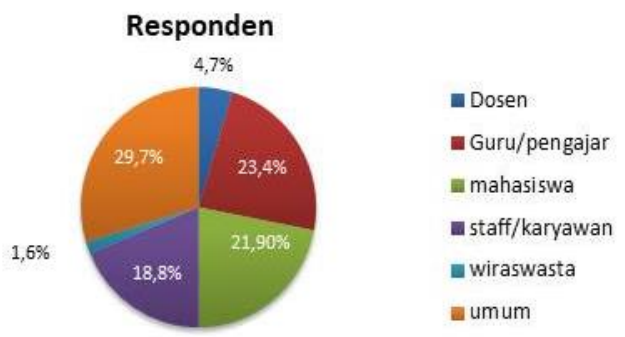

Tanggapan responden yang mencakup beberapa sikap-sikap ilmiah seperti sikap ingin tahu, sikap kritis, terbuka dan objektif. Dapat dilihat pada gambar dibawah ini.

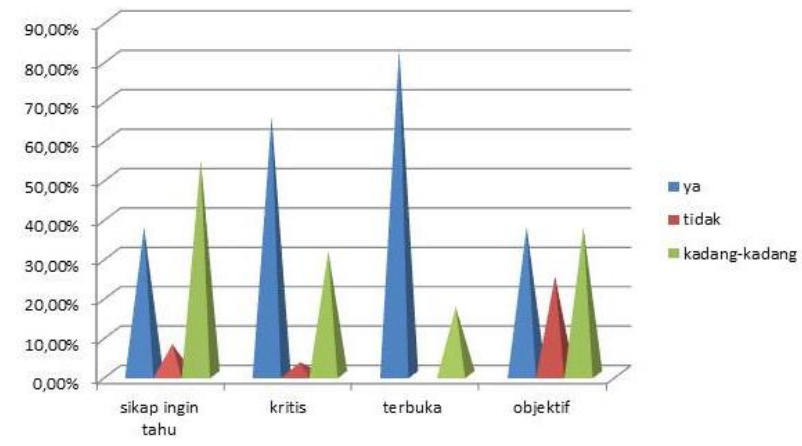

Dimensi berbagai sikap ilmiah yang diteliti dalam penelitian ini adalah rasa ingin tahu yang tinggi, sikap jujur, sikap kritis, sikap luwes, dan teliti. (Dimyati, 2013). Pada sikap keingintahuan reponden dihasilkan Sebesar 37,5\% responden mempunyai sikap selalu ingin tahu berita terbaru tentang covid-19, namun $7,8 \%$ tidak ingin tahu 
dan 54,7\% kadang-kadang responden ingin mengetahuinya. Keingintahuan informasi covid-19 ini didasari atas informasi yang sudah terlalu banyak beredar di berbagai media sehingga persentasenya lebih besar pada pilihan kadang ingin tahu kadang tidak karena terkadang ada yang menyebarkan berita hoax (Rahayu \& Sensusiyati, 2020). Seperti berasal dari sumber hasil penelitian yang telah meriview tentang penelusuran tentang tiga topik pemberitaan yaitu terjangkitnya penyakit yang disebabkan virus corona, pengobatan dan perilaku masyarakat dalam mencegah virus covid-19. Situs resmi kominfo juga selalu memberikan peringatan tentang adanya berita hoax mengenai virus corona (Rahayu \& Sensusiyati, 2020). Hal tersebut juga dapat berdampak pada besarnya sikap ilmiah kritis responden dalam mencari informasi mengenai covid-19 seperti gejala, penyebaran dan pencegahannya sebesar $65,6 \%$, sedangkan 3,1\% tidak dan 31,3\% kadang-kadang.

Sikap terbuka responden tentang mengikuti anjuran dari pemerintah seperti mengikuti protokol kesehatan didapatkan hasil sebesar $82,8 \%$ mematuhinya dan 17,2\% menjawab kadang-kadang. Pada Sikap ilmiah objektiif sebesar 37,5\% responden menjawab jika mereka bertemu dengan orang yang tidak menerapkan protokol kesehatan di suatu tempat umum, maka akan menegurnya, 25\% tidak dan 37,5\% menjawab kadang-kadang. Menurut (Thorik, 2020) sikap ilmiah adalah berbagai sikap yang ditunjukkan oleh para ahli saat mereka melaksanakan suatu kegiatan sebagai seorang ilmuwan. Hal ini bahwa setiap individu ini melakukan suatu tindakan atau perilaku dalam menyelesaikan suatu masalah secara tertatata dan berurutan sesuai langkah-langkah ilmiah (Umar, 2012). The Liang Gie (Ertanti, 2016) berpendapat bahwa sikap ilmiah adalah suatu individu seorang ahli dalam berperilaku atau dalam memunculkan tanggapan mengenai berbagai hal sesuai dengan hasil pemikiran ilmiahnya atau tidak bertentangan dengan bidang keilmuwan umumnya. (Sardinah, Tursinawati, \& Noviyanti, 2012) berpendapat bahwa sikap ilmiah merupakan cara pandang seseorang terhadap suatu cara berpikir yang sesuai dengan tata keilmuan, sehingga muncullah kecenderungan dalam menerima atau menolak suatu pemikiran yang sesuai dengan bidang keilmuan tersebut. Seorang ahli ilmuwan wajib mempunyai sikap yang baik, atau menerima pemikiran yang sesuai dengan metode bidang keilmuan, yang disimpan di dalam pengetahuannya, perasaan dan emosinya serta di dalam perilakunya. Penggolongan berbagai sikap ilmiah yang dikemukakan oleh para imuwan sangat bervariasi dan bermacam-macam.

Kebaharuan dari penelitian ini adalah melihat sisi pandemi covid-19 ini selain dari pengetahuan tetapi juga menganalisi perilaku serta sikap ilmiah yang mencakup rasa ingin tahu yang tinggi, sikap jujur, sikap kritis, sikap luwes, dan teliti.

\section{Kesimpulan}

Kesimpulan didapatkan dari penelitian ini bahwa masyarakat dari berbagai kalangan mempunyai sikap keingintahuan seperti selalu ingin tahu berita terbaru tentang covid-19, bersikap kritis dalam mencari informasi mengenai covid-19 seperti gejala, penyebaran dan pencegahannya, sikap terbuka tentang mengikuti anjuran dari pemerintah seperti mengikuti protokol kesehatan dapat dilihat dari kebiasaan baru mereka yang selalu mengikuti protokol kesehatan seperti memakai masker, mencuci tangan, menjaga jarak dan menghindari kerumunan. 


\section{Bibliography}

Buana, Dana Riksa. (2020). Analisis Perilaku Masyarakat Indonesia dalam Menghadapi Pandemi Virus Corona (Covid-19) dan Kiat Menjaga Kesejahteraan Jiwa. SALAM: Jurnal Sosial Dan Budaya Syar-I. https://doi.org/10.15408/sjsbs.v7i3.15082

Buana, Riska Dana. (2017). Analisis Perilaku Masyarakat Indonesia dalam Menghadapi Pandemi Covid-19 dan Kiat Menjaga Kesejahteraan Jiwa. Sosial Dan Budaya, Fakultas Syariah Dan Hukum Universitas Islam Negeri (UIN) Syarif Hidayatullah Jakarta.

Dimyati, Mudjiono dan. (2013). Model-model pengajaran dan pembelajaran. Teaching and Educations.

Ertanti, Devi Wahyu. (2016). PENERAPAN MODEL PEMBELAJARAN KOOPERATIF TIPE NHT PADA MATA PELAJARAN IPA UNTUK MENINGKATKAN PRESTASI BELAJAR SISWA KELAS V SEKOLAH DASAR. MODELING: Jurnal Program Studi PGMI.

Iqbal, Muhammad, Simarmata, Janner, Feriyansyah, F., Tambunan, Anna Riana Suryanti, Sihite, Onggal, Gandamana, Apiek, Eza, Gita Noveri, Kurniawan, Fauzi, Asiah, A., Rozi, Fahrur, Faisal, F., Manurung, Imelda Free Unita, Ihwani, Mohamad, Nathan, Putri Lynna Adelinna, Sitanggang, Nathanael, Simbolon, Naeklan, Simanjuntak, Eva Betty, \& Limbong, Tonni. (2018). Using Google form for student worksheet as learning media. International Journal of Engineering and Technology(UAE). https://doi.org/10.14419/ijet.v7i2.29.13646

Julianti, R., Nasirun, M., \& Wembrayarli, W. (2018). PELAKSANAAN PERILAKU HIDUP BERSIH DAN SEHAT (PHBS) DI LINGKUNGAN SEKOLAH. Jurnal Ilmiah Potensia. https://doi.org/10.33369/jip.3.2.76-82

Rahayu, Rochani Nani, \& Sensusiyati. (2020). Analisis Berita Hoax Covid - 19 Di Media Sosial Di Indonesia. Jurnal Ekonomi, Sosial, \& Humaniora.

Sardinah, Tursinawati, \& Noviyanti, Anita. (2012). Relevansi Sikap Ilmiah Siswa Dengan Konsep Hakikat Sains Dalam Pelaksanaan Percobaan Pada Pembelajaran Ipa Di Sdn Kota Banda Aceh. Jurnal Pendidikan Serambi Ilmu.

Sugiyono. (2012). Metode Penelitian Kuantitatif, Kualitatif dan $\mathrm{R}$ \& D.Bandung:Alfabeta. Metode Penelitian Kuantitatif, Kualitatif Dan $R \quad \&$ D.Bandung:Alfabeta. https://doi.org/10.1017/CBO9781107415324.004

Sugiyono, Prof. Dr. metode penelitian kuantitatif, kualitatif,dan R\&D. , Alfabeta, cv. (2016).

Surajiyo, \& Sriyono. (2017). Sikap Ilmiah Ilmuwan. Prosiding Diskusi Panel Pendidikan "Menjadi Guru Pembelajar" Keluarga Alumni Universitas Indraprasta PGRI. 
Eka Kartikawati, Ranti Annisa dan Maesaroh

Thorik, Sylvia Hasanah. (2020). Efektivitas Pembatasan Sosial Berskala Besar Di Indonesia Dalam Penanggulangan Pandemi Covid-19. Jurnal Adalah: Buletin Hukum Dan Keadilan.

Tri Wibawanto, M. Si. (2020). PEMANFAATAN GOOGLEFORM SEBAGAI MEDIA PEMBELAJARAN JARAK JAUH ATASI PENYEBARAN COVID-19. Journal of Chemical Information and Modeling.

Umar, Husein. (2012). Penelitian Kuantitatif Langkah Demi Langkah. Pelatihan Metodologi Penelitian Kopertis III.

World Health Organization. (2020). WHO Timeline COVID-19. 